\title{
Foreign Direct Investment Inflows into Zimbabwe
}

\author{
Mike Nyamazana Sikwila
}

Department of Consumer Science, Chinhoyi University of Technology

Godwell Karedza

Department of Marketing, Chinhoyi University of Technology

\section{Yvonne Lindiwe Sikwila}

National University of Science and Technology, Bulawayo, Zimbabwe

Doi: 10.2478/mjss-2018-0095

\section{Abstract}

The authors sought to explore factors that influenced foreign direct investment (FDI) in Zimbabwe between 1990 and 2014. In spite of Zimbabwe being one of the richest countries, with respect to mineral endowment in the Southern African Development Community (SADC) region there was a paradox of less FDI attracted into the country. We include the investment policy stability (IPS) variable that has been ignored in the current literature; yet, the investment centre policies in any given developing country influence FDI inflows. The authors used Ordinary Least Square regression analysis technique to estimate an investment equation for Zimbabwe using Time-Series annual data obtained from the UNCTAD and World Bank database. The results suggest that investment policy stability; trade openness of the country; inflation rate and growth in real domestic product have a significant influence on the FDI inflows into the country. In conclusion, the results suggest that investment policy stability played an important role in attracting FDI into the country. Also, the results are expected to give a useful insight to policymakers that are responsible for attracting FDI inflows into Zimbabwe and other developing countries.

Keywords: Foreign Direct Investments; inflows, Zimbabwe

\section{Introduction}

Stylized fact ${ }^{1}$ : 'A country's favorable overall outlook with respect to institutional arrangement, socioeconomic and political aspects attracts foreign direct investment'.'

The underlying fact is that countries could move from their underdeveloped state into progressive economic development. For instance, in South-East Asian countries that include: Malaysia, Singapore, South Korea, Indonesia and Thailand that exhibited fast growth rates between the 1960s and 2014 were once poor, yet, have managed to transform their economic, social and political structures, and thereby attracting FDI that complemented the fast economic growth and

\footnotetext{
${ }^{1}$ Stylized facts: see, Kaldor (1961:178)
} 
development. Foreign direct investment in the era of globalization has become one of the essential sources of employment, technological transfer, economic growth and development, in both developed and developing countries. The global FDI inflows decreased in 2014 by $16 \%$ from US\$1.47 trillion in 2013 to US\$1.23 trillion by 2014 (UNCTAD, 2015). The global decline in FDI inflows in 2014 could have been precipitated by specific country risks in various regions. In 2014 the developed countries attracted US $\$ 681$ billion of the total FDI inflows (UNCTAD, 2015). Notwithstanding the global decline in total FDI inflows, the developing countries recorded an increase in FDI inflows of $2 \%$ giving a figure of US $\$ 681$ billion which was $55 \%$ of global FDI inflows in 2014 (UNCTAD, 2015; 2014). Most of the FDI inflows to developing countries went to developing Asian economies and Latin America. The South and East Asian countries saw a growth in FDI of $9 \%$ (US\$465 billion) which was a substantial share of the total FDI inflows to developing countries in 2014 (UNCTAD, 2015). Africa's overall FDI inflows remained constant between 2013 and 2014 at US\$54 billion, while Latin America and Caribbean recorded a 14\% (US\$159 billion) decline in 2014 (UNCTAD, 2015).

In view of the above global FDI profile, we examine the performance of FDI in Zimbabwe covering the period between 1990 and 2014. Most of the FDI in Zimbabwe over the period was resource - seeking in the mining (gold, diamonds and platinum) sector. In addition, the FDI inflows into Zimbabwe are the horizontal type (Alfaro, 2017: S9), particularly from South Africa where the parent company extends its current operations across borders. The vertical FDI in which the affiliate in host-country are linked with parent firm and produce inputs for the parent firm are relatively few in Zimbabwe. An analysis of the FDI profile and its determinants in Zimbabwe is expected to give an insight to the policy makers and investment centre institutions seeking to attract FDI into the country. To improve the standard of living for the majority of Zimbabweans the country needs to produce more goods and services for the population. Notably, in 2015, United Nations reports per capita nominal GDP of US $\$ 890$ in Zimbabwe, which was relatively lower, ranked at 167 in the world out of 194 countries (Wikipedia, 2017). However, in the absence of significant savings to achieve a relatively high economic growth rate the country needs, in part, foreign direct investment. It stands to reason therefore, that the overarching country's desire in its attempt to fight the grip of poverty and improve the standard of living is to grow the economy.

The problem is that the relatively slow increase of FDI into Zimbabwe between 1990 and 2014 contributed, in part, to poor economic growth and grip of poverty for the majority of the population. The motivation to carry out the study was stirred by the need to identify and estimate the key factors that influence foreign direct investment in Zimbabwe. The purpose of the study is to establish the key factors that influence the flow of foreign direct investment into developing countries such as Zimbabwe. The research questions are twofold; first, what are the key factors that influence the flow of foreign direct investment into developing countries such as Zimbabwe? Second, why is direct investment in Zimbabwe increasing relatively more slowly than in other countries in Southern African Development Community (SADC) region, despite its endowment of natural mineral resources such as diamonds, gold and platinum? The study is important in that it provides an insight to policy makers into the requirement that multinational firms look for before choosing a country as a destination for foreign direct investment. Also, direct foreign investment is essential in creating new jobs and thereby alleviating the grip of poverty in the country. In addition, foreign direct investment augments domestic investment required for economic growth and development.

We employed the Ordinary Least Squares regression equation to estimate the foreign direct investment (FDI), the dependent variable, against growth rate in real gross domestic product; investment policy stability, trade openness of a country, and inflation using Eviews7 statistical program on annual time-series data. The annual data was sourced from the UNCTAD and World Bank databases. The sources are justified in that they collect data for all countries, thereby making it possible to compare performance of various countries. Most of the studies barely show the theoretical foundation that persuades firms or country to invest. On the methodological aspects our point of departure from the current studies is the use of the acceleration principle (Junankar, 1972; Bean, 1982) to explain the desire of firms and countries to invest and/or cover the capital stock gap in order to produce more output or respond to increased demand. The recent studies (Kaur and 
Sharma, 2013; Hwang and Seade, 2014; Mahembe and Odhiambo, 2014; Hoang and Goujon, 2014, Sikwila, 2015; Alfaro, 2017) have examined several determinants of FDI, but have ignored investment policy stability per se often undertaken by the Investment Centre (IC) of individual countries in developing nations. The investment centres are important institutions in developing countries in that they are mandated to attract FDI and give advice to governments on direct investment policies. We therefore, sought to use new data and variables to examine the influence of investment policy stability. Also, the study further substantiates the applicability of the acceleration theory of investment in different settings and time period.

The results indicate that, Investment policy stability, trade openness, growth rates in GDP and inflation rate had a significant influence on investment inflows into Zimbabwe. In particular, the results suggest that the investment policy stability variable overlooked by previous studies complements traditional variables included in the model in attracting FDI inflows. The results also complement current literature on FDI inflows in developing countries such as Zimbabwe. We conclude that close attention by policymakers to the mentioned variables was expected to produce a positive effect on FDI inflows that would, in turn, augment domestic investment and improve employment opportunities, economic growth and per capita income in Zimbabwe.

The study is divided into five sections: Section One gives the introduction and summarizes FDI profiles in both developed and developing nations. Section Two examines previous studies on the determinants of FDI inflows to host country. Section Three presents the methodology and theoretical framework that informs and assert the motivation to invest by firms. In Section Four we carry-out an estimation of investment equation and present results and discussions. Finally, Section Five give the conclusion.

\section{Literature Review}

\subsection{Zimbabwe FDI profile}

The FDI inflows into Zimbabwe have been erratic between 1990 and 2012 (see, figure 1). Following the structural adjustment and liberalization of the economy between 1990 and 1996, the FDI inflows picked-up from US\$12 million to US\$118 million per year. The following years $1997-1999$ the FDI inflows increased from US\$81 million to US\$444 million per year. However, the up-ward trend in the FDI inflows was short lived in that between 2001 and 2010 the FDI inflows were disappointing (see, figure 1). The decade (2001-2010) experienced erratic investment inflows into Zimbabwe which averaged US\$43 million.

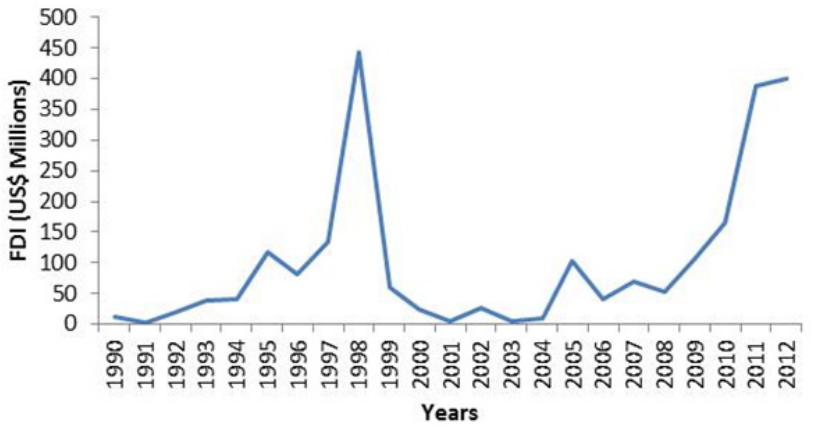

Figure 1: Zimbabwe FDI Inflows (US\$ millions)

Source: Data from UNCTAD 2015, FDI/TNC database 
Comparing the average figure of US\$43 million in the decade (2001-2010) for Zimbabwe with that of neighbouring countries per country, the average FDI inflows into Zimbabwe were relatively lower than that of each neighbouring country. For example, between 2001 and 2010 the average FDI inflows for Botswana was US\$337 million; Mozambique US $\$ 454$ million; Malawi US\$87 million; Namibia US\$445 million, Zambia US\$536million and South Africa US\$4373 million (UNCTAD, 2015). Following the unity government 2009 through to 2012 the FDI inflows into Zimbabwe picked-up from US\$52 in 2009 to US\$400 million per year (Figure 1). But the average FDI inflows (2001-2010) of US\$43 million into Zimbabwe were relatively small compared to FDI inflows into the whole of the Southern African Development Community (SADC) which recorded an average of US $\$ 7223$ million. The FDI inflows into Zimbabwe were just $0.6 \%$ of the average FDI inflows into SADC region (UNCTAD, 2015).

As have been already mentioned, looking at the averages of the FDI inflows into SADC countries (UNCTAD, 2015), Zimbabwe was relatively the least attractive FDI destination among the six neighbouring countries, namely Botswana, Mozambique, Malawi, Namibia, Zambia and South Africa. The question that has not yet been fully answered is why Zimbabwe attracts relatively less FDI when it is endowed with abundant natural resources. It was against this background that we sought to investigate the determinants that influenced FDI inflows into Zimbabwe. The question of what are the determinants of FDI in Zimbabwe is far from being resolved considering the poor FDI inflows into the country. Table 1 shows the performance of FDI over a decade in five selected Southern African countries, South Africa, Mozambique, Namibia, Zambia and Zimbabwe. All the countries shown on table1 have outperformed Zimbabwe between 2005 and 2014 in terms of FDI inflows.

Table 1: FDI US\$ Millions For selected Southern African Countries (2003-2012)

\begin{tabular}{lllllllllll} 
Years & $\mathbf{2 0 0 5}$ & $\mathbf{2 0 0 6}$ & $\mathbf{2 0 0 7}$ & $\mathbf{2 0 0 8}$ & $\mathbf{2 0 0 9}$ & $\mathbf{2 0 1 0}$ & $\mathbf{2 0 1 1}$ & $\mathbf{2 0 1 2}$ & $\mathbf{2 0 1 3}$ & $\mathbf{2 0 1 4}$ \\
\hline South Africa & $\mathbf{6 6 4 7}$ & $\mathbf{3 1 2}$ & $\mathbf{6 5 3 8}$ & $\mathbf{9 2 0 9}$ & $\mathbf{7 5 0 2}$ & $\mathbf{3 6 3 6}$ & $\mathbf{4 2 4 3}$ & $\mathbf{4 5 5 9}$ & $\mathbf{8 3 0 0}$ & $\mathbf{5 7 1 2}$ \\
Mozambique & 108 & 113 & 399 & $\mathbf{5 9 2}$ & $\mathbf{8 9 8}$ & $\mathbf{1 0 1 8}$ & $\mathbf{3 5 5 9}$ & $\mathbf{5 6 2 9}$ & $\mathbf{6 1 7 5}$ & $\mathbf{4 9 0 2}$ \\
Namibia & $\mathbf{3 5 5}$ & $\mathbf{3 8 7}$ & $\mathbf{7 3 3}$ & $\mathbf{7 2 0}$ & $\mathbf{5 0 6}$ & $\mathbf{7 9 3}$ & $\mathbf{8 1 6}$ & 1133 & $\mathbf{8 0 1}$ & $\mathbf{4 1 4}$ \\
Zambia & $\mathbf{3 5 7}$ & $\mathbf{6 1 6}$ & 1239 & $\mathbf{9 3 9}$ & $\mathbf{4 2 6}$ & $\mathbf{6 3 4}$ & 1110 & $\mathbf{2 4 3 3}$ & $\mathbf{1 8 1 0}$ & $\mathbf{2 4 8 4}$ \\
Zimbabwe & 103 & $\mathbf{4 0}$ & $\mathbf{6 9}$ & $\mathbf{5 2}$ & $\mathbf{1 0 5}$ & 166 & $\mathbf{3 8 7}$ & $\mathbf{4 0 0}$ & $\mathbf{4 0 0}$ & $\mathbf{5 4 5}$ \\
\hline
\end{tabular}

Source: UNCTAD, FDI/TNC database (www.unctad.org/fdistatistics); various issues.

South Africa was the most favored destination of FDI followed by Mozambique and Zambia at the end of 2014. Although Zimbabwe tipped Namibia at the end of 2014 on the average and year on year Namibia has had more FDI inflows compared to Zimbabwe.

\subsection{FDI theory}

In an effort to explain why multinational corporations (MNC) preferred certain destinations to invest compared to others, Dunning (1973, 1979, 1980, 2000, 2001,), explains that the motivation to invest in the specific countries was based on three pillars. First the ability of the MNC to persuade the host country to allow it to establish its subsidiary in the country was important in that host country's conditions regarding foreign investment was to be observed (Sikwila, 2015; Ramirez, 2006, Dunning, 2000).

Notably, the host country would, perhaps, assent to MNC investment for several reasons that include: transfer of technology and creation of new employment opportunities. Once the establishment of a subsidiary and/or affiliates was accomplished, the MNC would then win the protection of the host government and its people against other competitors. Subsequently, enabling the MNC to assert ownership advantages, over its endowment of the intellectual property rights, such as: commercial secrets, patents, trademarks, brands and production techniques (Ramirez, 2006; Dunning, 2000) that they possess.

Second, the establishment of MNC in the host country implied locating itself among the domestic firms and/or it was recognized as a domestic company, albeit allowed, by the host country, to repatriate profits and dividends to the parent company. Given the location advantage, 
the MNC could then hire cheap labor, exploit cheap raw material at low transport costs and other inputs that were critical to its production needs (Ramirez, 2006). Third, Dunning (1988), explains that the MNC, also derived other advantages accruing from internalization of its operations, such as marketing of its products domestically. However, the assertion by Dunning (2000) augments Hymer (1976) who put forward a theory from the industrial organization ${ }^{2}$ perspective that has been widely accepted to explain the MNC decision to locate FDI in particular destinations. According to Calvet (1981), monopoly structures lead to market imperfections and market failure and thereby suppress competition. Subsequently, the MNC move into the host-country where the monopolies exist to create competition (Calvet, 1981).

\subsection{Related studies}

In our undertaking of literature review of the determinants of FDI in less developing countries (LDCs), we examine the factors that have been generalized as having an influence on FDI in LDCs. These include economic factors, favorable government policies and regulations, and current infrastructure. Economic Factors: The macroeconomic factors that are documented as having an influence on FDI include: economic growth, inflation, unemployment, per capita income and exchange rate.

Alfaro (2017), examines the benefits of FDI to host-country at both micro and macro level of activity and concluded that FDI inflows to host country were beneficial in that it brought with it technology, knowledge transfer and improved capital stock that led to an increase in employment and economic growth. A country that allowed competitive market structure to take root and a relatively liberal economic environment that complement the traditional determinants of FDI (Harrison and Rodriguez-Clare, 2010; Alfaro, 2017), was expected to induce more FDI inflows.

In a study of FDI inflows into India using Ordinary Least Square technique on quarterly data, Kaur and Sharma (2013), found that GDP openness and Reserve foreign exchange had a significant positive influence, while inflation had a negative effect. On the contrary, Asheghian (2011), employed causality technique on FDI and economic growth and found that FDI had no influence on economic growth in Canada. In support of Asheghian (2011), a study by Jilenga, Xu and Gondje-Dacka (2016), reports that FDI inflows had insignificant effect on economic growth rates in Tazania. In a similar study, Sothan (2017) examined the causal link between FDI and economic growth in Cambodia and concluded that FDI had a strong effect on economic growth in Cambodia. Blonigen and Piger (2014), employed a Bayesian statistic technique that select variables to be included from many variables available, and concluded that most variables used in the previous studies were not robust (Blonigen and Piger, 2014:775). The weakness of the approach was that one cannot choose from a host of variables which ones would attract FDI, because countries' institutional arrangements differ from one another.

Rjoub et al. (2016), examined the link between FDI and economic growth of (7) Latin American countries, and found that lagged FDI had a positive influence on economic growth. Also, the study reports that trade openness and human capital were important determinants of FDI inflows. Blanco (2012) argues that countries with natural resources attract FDI inflows in Latin America. Egan (2010) avers that FDI contributes to improvement onto capital infrastructure, technology and management skills in host-countries. On examination of 37 countries from various regions that include Africa, Asia and Latin America, Neelankavil, et al. (2011) concluded that FDI had a positive effect on economic growth in the long run. The argument suggests that the capital accumulation over the long term had a significant role onto economic growth and development of the country. Study by Ramirez (2006) found that exchange rate and debt service ratio were significant determinants of FDI in flows into Chile. The finding is not surprising in that most developing countries often lack foreign exchange required on repatriation of profits and dividends to foreign investors. We argue, therefore, that studies on the impact of FDI on economic growth rate were inconclusive and that further research was necessary.

\footnotetext{
${ }^{2} \mathrm{FDI}$ is an off spring of market imperfections, suggesting that if markets exhibit perfect competition there could be no need for MNC and FDI (Hymer, 1976; Calvet, 1981).
} 


\section{Methodology and Data}

The fundamental assumption was that FDI adds to capital stock of a country which, in turn, improves output over years. Subsequently, the increase in output was expected to induce more direct investment. We further assume that the less developing country experience excess demand for goods and services and that the shortage of goods and services persuade the host-country to accumulate capital stock from FDI into various sectors of the economy, and thereby leading to more consumption and investment. The secondary annual data of 30 observations was obtained from the UNCTAD and World Bank databases and used to estimate the foreign direct investment equation.

\subsection{The model}

There are several studies on FDI determinants that have examined various economic and noneconomic factors that influence FDI inflows into a particular country or region. As the literature review section has shown, the factors include: growth rates in the Gross domestic product, interest rates, trade openness; market size, infrastructure, ownership; location and internalization, among other things. On the methodological aspects our point of departure from the current studies is that we use the acceleration principle (Junankar, 1972; Bean, 1982, Sikwila, 2015) to explain the desire of firms and country to invest and/or cover the capital stock gap in order to produce more output or respond to increased permanent demand. We follow a simple acceleration theory that asserts that aggregate investment is a proportion of the level of output for both firms and country. Thus, we assume that the present capital stock of a firm and/or country was determined by previous outputs given as;

$$
\Psi_{t}=F\left(Q_{t}, Q_{t}, Q_{t} Q_{t-n}\right)
$$

Where $\Psi$ is present capital stock; $t$, is the per unit time; $F$ is the function operator; $Q$ is output. We further assume that the previous outputs that determine the capital stock $\Psi_{t}$ have weights that decline geometrically given as;

$$
\Psi_{\mathrm{t}}=v(1-\tau) \sum_{i=0}^{\infty} \tau^{i} Q_{t-i}(0<\tau<1)
$$

The weights $(1-T),(1-T) T,(1-T) T^{2},(1-T) T^{3} \ldots$, it follows then that $(1-T) \Sigma T^{i}=1$. Furthermore, we lag equation (2) and multiply by $\mathrm{T}$ to obtain equation (2) and (4) given as follows;

$$
\Psi_{\mathrm{t}-1}=v(1-\tau) \sum_{i=0}^{\infty} \tau^{i} Q_{t-i-1}
$$

And equation (4) obtained by multiplying equation (3) through by t gives;

$$
\tau \Psi_{\mathrm{t}-1}=v(1-\tau) \sum_{i=0}^{\infty} \tau^{i+} Q_{t-i-1}
$$

Subtracting equation (4) from equation (2) we obtain the Koyck transformation (Koyck, 1956) given as;

$$
\Psi_{\mathrm{t}}-\mathrm{T} \Psi_{\mathrm{t}-1}=(1-\mathrm{T}) \mathrm{U} Q_{\mathrm{t}}
$$

Further subtracting $\Psi_{\mathrm{t}-1}$ on both sides of equation (5) we obtain;

$\Psi_{\mathrm{t}}-\Psi_{\mathrm{t}-1}=(1-\mathrm{T}) \mathrm{UQ}_{\mathrm{t}}-(1-\mathrm{T}) \Psi_{\mathrm{t}-1}$

We assume depreciation to be a proportion of previous capital stock given as $\gamma C \Psi P_{t-1}$ and $\gamma$ is between zero and one $(0<\gamma<1)$. Since we are interested in gross investment $\uparrow_{t}^{G}$ in a given time we add on both sides of equation (6) depreciation to give us;

$t_{t}^{G}=\Psi_{t}-\Psi_{t-1}+\gamma \Psi_{t-1}=(1-T) \cup Q_{t}-(1-T-\gamma) \Psi_{t-1}$

In equation (7) $\Psi_{t}-\Psi_{t-1}$ represents net investment $\left(t_{t}^{N}\right)$ responsible for building up capital stock from actual to desired level. The investment path followed by the firm or country will depend on the cost of investment. We assume the firm and/or country's long term desired capital stock $\Psi^{*}$ when achieved gives;

$\Psi_{\mathrm{t}}^{\star}=\Psi_{\mathrm{t}}$

Thus, ignoring the lags, desired capital stock is equal to a proportion of output, emphasizing 
the acceleration principle, and thereby linking the size of desired capital stock concept with investment theory. Further substituting equation (8) into equation (5) we obtain the flexible accelerator given as;

$$
t_{\mathrm{t}}^{\mathrm{N}}=\Psi_{\mathrm{t}}-\Psi_{\mathrm{t}-1}=(1-\mathrm{T})\left(\Psi_{\mathrm{t}}^{*}-\Psi_{\mathrm{t}-1}\right)
$$

Equation (9) states that net investment $\left(t^{\mathrm{N}}{ }_{t}\right)$ is the gap between desired capital stock and actual capital in the preceding period. However, firm and/or country would, perhaps, not cover the required net investment at once, but take time depending on the cost of investment and availability of finance. It follows that net investment was a fraction of the gap between desired and actual capital stock. The coefficient (1- T) indicates the speed of adjustment per unit time. The lag factor was among other things due to decision and ordering and delivery lags.

\subsection{Model Specification}

A modification of the flexible accelerator to include other variables that affect the country gives the function;

$\mathrm{FDI}=\mathrm{FDI}\left(\mathrm{GRGDP}, \mathrm{IPS}, \mathrm{TOPEN}_{\mathrm{t}}, \mathrm{INF}_{\mathrm{t}}, \xi\right)$

Where FDI is foreign direct investment inflows; GRGDP is growth rate in gross domestic product; IPS is the investment policy stability represented by the dummy variable, where ' 0 ' before policy change and ' 1 ' after policy change. The IPS variable has been ignored in the current literature; yet, the investment centre policies in any given country influence FDI inflows. The TOPEN is trade openness of a country to both investment and goods and services. The trade openness was taken as a proportion of exports plus imports to gross domestic product. Trade openness encompasses exports and imports essential in earning foreign exchange and improvement of balance of payment, which, in turn, should enable the country to acquire capital equipment, and intermediate goods for production. Also, the purchase of medicines, utilities such as electricity and water treatment that require foreign exchange underlies the importance of trade openness to foreign investors. INF is inflation rate a rise in general prices over time and " $\xi$ " is the stochastic random variable. The log-linear form of equation (10) is given as;

$$
\log F D I_{t}=\beta_{0}+\beta_{1} \log G R G D P_{t}+\beta_{2} \log I P S_{t-1}+\beta_{3} \log T O P E N_{t}+\beta 4 \log I N F_{t}+\xi
$$

Equation (11) state that, all other things being equal, FDI was positively influenced by growth rates in real GDP; the lagged investment policy stability, and trade openness while inflation rate negatively influenced FDI.

\subsection{Testing for unit roots}

We assume the viable " $Z$ " represents any of the variables in equation (1) and we test if the variable " $Z_{t}$ " was stationary, implying that its variance and mean were stable over the long term period. A stationary " $Z_{t}$ " imply that $Z_{t} \rightarrow I(0)$ the order of integration, then " $Z_{t}$ " need to be differenced I(1) once or more to obtain stationarity (Dickey and Fuller, 1979). The autoregressive equations that underlie the testing for unit roots are given as;

$$
\begin{aligned}
& \mathrm{Z}_{\mathrm{t}}=\Psi+\phi \mathrm{Z}_{\mathrm{t}-1}+\xi_{\mathrm{t}} \\
& \mathrm{Z}_{\mathrm{t}}-\mathrm{Z}_{\mathrm{t}-1}=\psi+\phi \mathrm{Z}_{\mathrm{t}-}-\mathrm{Z}_{\mathrm{t}-1}+\xi \\
& \Delta \mathrm{Z}_{\mathrm{t}}=\psi+(\phi-1) \mathrm{Z}_{\mathrm{t}-1}+\xi \\
& \text { If } \phi=0 \text { (stationary) and when } \phi=1 \text { (none-stationary; unit root) }
\end{aligned}
$$

The Augmented Dickey Fuller Tests (ADF) was used to test for the existence of a unit root. The null hypothesis that a unit root exists was tested against the alternative that there is no unit root. Presence of unit root implies that the variables are none stationary leading to wrong inference during results interpretation. Differencing tests were done on all variables in their levels and results are shown in Table 2. All the probability value of ADF statistic were compared to $0.01,0.05$ and $0.1^{2}$ and any probability value of a variable below these three values was considered to be stationary. 
Table 2: Results of the Unit Root Test

\begin{tabular}{|c|c|c|c|}
\hline Variables & t-ADF & Critical-5\% & Conclusion \\
\hline GRGDP & -6.292453 & -1.952473 & $\mathrm{I}(1)$ \\
\hline DFDI & -2.779662 & -1.952066 & $\mathrm{I}(1)$ \\
\hline DIPS & -6.825073 & -1.952473 & $\mathrm{I}(1)$ \\
\hline DTOPEN & -7.117460 & -1.953381 & $\mathrm{I}(1)$ \\
\hline DINF & $-4.011155^{*}$ & -1.952066 & $\mathrm{I}(1)$ \\
\hline
\end{tabular}

*implies significant at 5\%; critical values where obtained for MacKinnon (1991).

Source: Computed from UNCTAD data base (2015)

Table 2 shows the unit root test results which were found to be significant and stationary and integrated of order I(1) at $5 \%$ levels. The results of the estimates of equation (11) are presented in Table 3.

\section{Results and Discussions}

Table 3: FDI Estimation

Method: Ordinary Least Squares Dependent Variable: FDI

\begin{tabular}{llll}
\hline Independent Variables & Coefficients & Std. Error & t-Statistics \\
\hline Growth: Domestic product & 2.45 & 0.93 & 3.15 \\
Investment policy stability & 2.51 & 0.56 & 4.48 \\
Trade Openness & 4.21 & 0.73 & 5.76 \\
Inflation Rate & -3.42 & 1.84 & -1.86 \\
& & & \\
$\mathrm{R}^{2}=67 \%$; Durbin-Watson Stas $=2.31$; Observations $=30$ &
\end{tabular}

Source: Computed from UNCTAD data base (2015)

The results of the estimate of foreign direct investment equation (11) shows that $67 \%$ of the variation in foreign direct investment was explained by growth rate in domestic product, investment policy stability, trade openness and inflation rate. The Durbin-Watson statistics (2.31) indicate the absence of autocorrelation among the error terms.

The growth in real domestic product (GRGDP) coefficient (2.45) was found to have a positive expected sign and was significantly different from zero. The positive t-ratio of 3.15 was significant at the $5 \%$ significant level, implying that economic growth positively influenced foreign direct investment, all other things being equal, emphatically supporting the acceleration theory of investment. The foreign investor was enticed by the performance of domestic firms. If domestic firms performed very well it attracted other firms to enter the market in an anticipation of making profits. Conversely, poor performance of domestic firms gave a negative picture of investment environment in the country.

The investment policy stability (IPS) presented by a dummy variable with values of ' 0 ' before policy change and a ' 1 ' after policy change, was found to be significant at the $5 \%$ level. The positive coefficient (2.51) indicates that an increase in investment policy stability positively influenced FDI inflows. The t-ratio of 4.48 was significant at the $5 \%$ level; implying that a relatively stable investment policy enticed foreign investors. Corollary, instability in investment policy measures led to uncertainty, and thereby less foreign direct investment. Investors often develop anxiety when faced with uncertainty of investment policy and longevity of the specific investment environment status quo. For this reason, investors expect consistent policy measures that ensure stability in their future profits earnings. It stands to reason, therefore, that countries with consistent clear and stable investment policies and regulations are expected to attract more foreign direct investment inflows.

The trade openness (TOPEN) of the country variable with a positive coefficient (4.21) was 
found to have a positive sign as expected. The t-ratio of 5.76 shows that the trade openness variable was significantly different from zero at the $5 \%$ level; implying that a relatively trade open and liberalized economy with acceptable trade and investment regulations to investors; positively attracted foreign direct investment. The trade openness allowed the foreign investor once in the host-country to import spare parts and other inputs required to carry out production activities. Subsequently, the evidence found in the study suggests that the country would attract more foreign direct investment if policymakers relaxed restriction on trade of goods and services for both essential exports and imports. Also, liberalized foreign exchange management was expected to influence or complement favorable environment to FDI inflows

Turning to inflation (INF), the coefficient of INF was found to possess the expected negative sign $(-3.42)$ and was significant with a t- ratio of -1.8 at the $10 \%$ level. The result suggests that inflation negatively influenced foreign direct investment. Implying that a persistent increase in general price level curtailed foreign direct investment. A persistent increase in the general price level was expected to adversely influence exchange rate, and thereby reducing the investors' earning power with respect to foreign currency required on repatriation of profits and dividends. Also, in part, persistent high inflation indicates a country's' inability to deal with macroeconomic fundamentals.

Notably, the results and findings differ from the previous studies in two ways: First, we demonstrate the importance of investment policy stability (IPS) often designed and implemented by Investment Centres at institutional level in LDCs has been overlooked in recent studies (Kaur and Sharma, 2013; Hwang and Seade, 2014; Mahembe and Odhiambo, 2014; Sikwila, 2015; Alfaro, 2017). The current study has shown that Investment centre policy stability influences FDI inflows in less developing countries. Second, the findings suggest that growth in output accelerates capital accumulation through previous and current FDI inflows, in that it was the long term capital accumulation that benefits the country. However, our findings, also, add to and support recent literature (Kaur and Sharma, 2013; Hwang and Seade, 2014; Mahembe and Odhiambo, 2014; Sikwila, 2015; Alfaro, 2017) on FDI inflows to both less developing and developed nations. Also, the findings, particularly the investment centre policy stability, provides an insight to investment Centres institutions involved in the promotion of FDI that was expected to improve employment, economic growth, tax revenue and per capita income in Zimbabwe and other developing countries.

\section{Conclusion}

The study of FDI inflows into Zimbabwe using the Time-Series annual data suggests that the investment policy stability, trade openness, real GDP and inflation rate influenced FDI inflows into the country. The results and findings are important to the investment centre institutions mandated to formulate investment policies and promote FDI inflows into the country. We suggest that Zimbabwe and other developing countries should focus their attention onto investment policy stability to improve on the policy clarity and consistence over the long term. A stable investment policy environment in Zimbabwe was expected to complement the Investment Centres promotion efforts and attract more FDI inflows. Furthermore, the relatively liberalized trade openness policies induced both domestic and foreign investment. We recommend that the investment Centre and country maintain and implement clear investment policies over the long term and avoid short term policy reversals. In addition, we recommend that LDCs adopt policies that increase consumer spending which, in turn, was expected to boost both domestic and FDI inflows in the long term. Future research would focus on how the vertical FDI inflows have impacted onto Southern African Development Community (SADC) economies.

\section{References}

Alfaro, L. (2017). Gains from Foreign Direct Investment: Macro and Micro Approaches. World Bank Economic Review, 30 Supplements 1, S2 - S15.

Asheghian, P. (2011). Economic Growth Determinants and Foreign Direct Investment Causality in Canada, International Jornal of Business and Social Sciences, 2(11), 1-9. 
Bean, C. R. (1981). An econometric model of manufacturing investment in the UK, The Economic Journal, 91, 106-121.

Blanco, L. (2012). The Spatial Interdependence of FDI in Latin America, World Development 40(7), 1337 1351.

Blonigen, B.A., and Piger, J. (2014). Determinants of Foreign Direct Investment, Canadian Journal of Economics, 47(3), $775-812$.

Calvet, A. L. (1981). A Synthesis of Foreign Direct Investment Theories and Theories of the Multinational Firm. Journal of International Business Studies, Spring/Summer, $43-57$.

Dickey, D. A., and Fuller, W. A. (1979). Distribution of the estimators for Autoregressive Time-Series with a Unit Root, Journal of the American Statistical Association, 74: 427-31.

Dunning, J. H. (1973). The determinants of International production. Oxford Economic Papers, November, 289 336.

Dunning, J. H. (1979). Explaining changing patterns of international production: In defence of the Eclectic Theory. Oxford Bulletin of economic and statistics, November, $269-295$.

Dunning, J. H. (1980). Toward an eclectic theory of international production: some empirical tests. Journal of International Business Studies, 11(1), 1, 9 - 31.

Dunning, J. H. (2000). The eclectic paradigm as an envelope for economic and business theories of MNE activity. International Business Review, 9, 163 - 190.

Dunning, J. H. (2001). The eclectic (OLI) paradigm of International Production: past, present and future. International Journal of the economics of business, 8(2), $173-190$.

Egan, P. J. W. (2010) Hard bargains: The Impact of multinational corporations on economic reform in Latin America, Latin American Politics and Society, 52(1): 1 - 32.

Harrison, A, and Rodriguez-Clare, A. (2010). "Trade, Foreign Investment, and Industrial Policy for Developing Countries." In Handbook of Development Economics, vol. 5, ed.Dani Rodrik, and Mark Rosenzweig, 4039 - 214. Oxford: North Holland.

Hoang, H. H and Goujon, M. (2014). Determinants of foreign direct investment in Vietnamese provinces: a Spatial econometric analysis, Post Communist Economies 26(1), $103-121$.

Hwang, H-C and Seade, J. (2014). Economic determinants of Inter- and Intra-FDI in East Asia, China Economic Policy Review, 2(2), 1 - 13.

Hymer, S. H. (1976). The International Operations of National Firms: A Study of Direct Foreign Investment. Cambridge. MA: MIT Press.

Jilenga, M.T., Xu, H., and Gondje-Dacka (2016). The Impact of External Debt and Foreign Direct Investment on Economic Growth: Empirical Evidence from Tazania, International Journal of Financial Research, 7(2), $154-162$.

Junankar, P. N. (1972). Investment: Theories and Evidence, London: Macmillan

Kaldor, N. (1961). Capital Accumulation and Economic Growth, 'In Lutz/Hague (eds.): The theory of capital, London, pp. 177-222.

Kaur, M and Sharma, R. (2013). Determinants of foreign direct investment in India: an empirical analysis. DOI 10.1007/s40622-013-0010-4, Springer, 40(1-2): 57-67

MacKinnon, J.G. (1991). Critical values for Cointegration Test, R.F. Engle and C.W.J. Granger (eds), in Longrun Economic Relationships: Readings in Cointegration. Oxford: Oxford University Press.

Mahembe, E and Odhiambo, N. M. (2014). Macroeconomic processes and regional economies management, Problems and perspectives in management, 12(1), 7 -16

Neelankavil, J., STvans, L. and Roman, F. (2011). Correlates of economic growth in developing countries: a panel cointegartion approach, International Review of Applied Economics 26(1): 83 - 96.

Ramirez, M. D. (2006). Economic and Institutional determinants of foreign direct investment in Chile: A TimeSeries analysis, 1960-2001, Contemporary Economic Policy, 24(3), 459-471.

Rjoub, H., Alrub, A.A., Soyer, K., and HAmdam, S. (2016). The Syndrome of FDI and Economic Growth: Evidence from Latin American Countries, Journal of Financial Studies and Research, vol 2016, Article ID5421185; pp 1-8.

Sikwila, M. N. (2015). Foreign direct investment: does it matter? A case for Zimbabwe, Research in Business and Economics Journal, Volume 11, 1 - 12.

Sothan, S. (2017). Causality between Foreign Direct Investment and Economic Growth for Cambodia. Cogent Economic and Finance, 5, 1277860, 1 - 13.

UNCTAD. (2015). World Investment Report, 2015: Reforming International Investment Governance, United Nationals, New York and Geneva.

Wikipedia (2017). List of countries by GDP (nominal) per capita. The Free Encyclopedia, htt://en.wikipedia.org/wiki/list-of-countries by GDP (nominal)-per-capita. retrieved 14 April 2017 time 15.38

World Bank (2013).Zimbabwe Overview. Retrieved on 12 August, 2015 from World Bank website: http/www.world-bank.org/en/country/Zimbabwe/overview. 